Louisiana State University

LSU Digital Commons

$4-1-2018$

\title{
Holocene vegetation and climate evolution of Corpus Christi and Trinity bays: Implications on coastal Texas source-to-sink deposition
}

\author{
Shannon Ferguson \\ Louisiana State University \\ Sophie Warny \\ Louisiana State University \\ John B. Anderson \\ Rice University \\ Alexander R. Simms \\ University of California, Santa Barbara \\ Gilles Escarguel \\ Université Claude Bernard Lyon 1
}

Follow this and additional works at: https://digitalcommons.Isu.edu/geo_pubs

\section{Recommended Citation}

Ferguson, S., Warny, S., Anderson, J., Simms, A., \& Escarguel, G. (2018). Holocene vegetation and climate evolution of Corpus Christi and Trinity bays: Implications on coastal Texas source-to-sink deposition. Geobios, 51 (2), 123-135. https://doi.org/10.1016/j.geobios.2018.02.007

This Article is brought to you for free and open access by the Department of Geology and Geophysics at LSU Digital Commons. It has been accepted for inclusion in Faculty Publications by an authorized administrator of LSU Digital Commons. For more information, please contact ir@lsu.edu. 


\section{UC Santa Barbara}

\section{UC Santa Barbara Previously Published Works}

\section{Title}

Holocene vegetation and climate evolution of Corpus Christi and Trinity bays: Implications on coastal Texas source-to-sink deposition

\section{Permalink}

https://escholarship.org/uc/item/0242h3qb

\section{Journal}

Geobios, 51(2)

ISSN

0016-6995

Authors

Ferguson, $\mathrm{S}$

Warny, S

Anderson, JB

et al.

Publication Date

2018-04-01

\section{DOI}

10.1016/j.geobios.2018.02.007

Peer reviewed 
1 Holocene vegetation and climate evolution of Corpus Christi and Trinity bays:

\author{
Shannon Ferguson ${ }^{\mathrm{a}, \mathrm{b}^{*}}$, Sophie Warny ${ }^{\mathrm{a}, \mathrm{b}}$, John B. Anderson ${ }^{\mathrm{c}}$, Alexander R. Simms ${ }^{\mathrm{d}}$, Gilles \\ Escarguel ${ }^{\mathrm{e}}$ \\ ${ }^{\text {a Department of Geology and Geophysics }}$ \\ ${ }^{\mathbf{b}}$ Museum of Natural Science, Louisiana State University, Baton Rouge, Louisiana, 70803 USA \\ 'Department of Earth Science, Rice University, Houston, Texas 77005, USA \\ ${ }^{\mathrm{d}}$ Department of Earth Science, University of California, Santa Barbara, California 93106, USA \\ 'Laboratoire d'Ecologie des Hydrosystèmes Naturels et Anthropisés, UMR CNRS 5023 LEHNA - \\ - Universite Claude Bernard Lyon 1, Villeurbanne Cedex, France \\ * Corresponding author: Shannon Ferguson (ferg.shannon@gmail.com)
}

\begin{abstract}
The Texas coastline stretches $595 \mathrm{~km}$ across almost $4^{\circ}$ of latitude and is home to diverse coastal vegetation assemblages, yet only a handful of studies have documented the climate and vegetative change of this region through the Holocene. We provide a detailed palynological record of Holocene climate for coastal Texas, based upon three subaqueous sediment cores from Corpus Christi Bay, TX and Trinity Bay, TX. Cluster analysis and correspondence analysis were used to investigate changes in palynological assemblages through time within each core. Common to both bays are nonarboreal taxa including Asteraceae (mainly Ambrosia, and Helianthus), Chenopodium, Poaceae, and arboreal taxa such as Carya, Pinus, and Quercus. Our record shows that the coastal environments of central Texas began a transition from herbaceous (nonarboreal) dominated vegetation to arboreal vegetation as early as $8.4 \mathrm{ka}$ within Corpus Christi Bay, and 3.8 ka within Trinity Bay. We note flooding events at $8.2 \mathrm{ka}, 5.4 \mathrm{ka}$, and $3.6 \mathrm{ka}$ in Corpus Christi Bay, and at $1.7 \mathrm{ka}, 1.2 \mathrm{ka}$, and $0.8 \mathrm{ka}$ in Trinity Bay. These events are caused by storms, changes to sea level including flooding of relict river terraces, and changes in sediment delivery to the bays. The pollen record also shows evidence for changes in fluvial discharge to Corpus Christi Bay at $4.1 \mathrm{ka}$ and $2.2 \mathrm{ka}$, and at $1.8 \mathrm{ka}$ in Trinity Bay. We also see Zea mays in Trinity Bay, indicating local Native American agriculture. We observe no significant changes during the middle Holocene Climatic Optimum, and subtle, but not statistically significant, evidence of more variable climate oscillations than other records from more interior sites in Texas show for the late Holocene. This indicates that coastal Texas' climate has operated semi-independently from central Texas regions, and is primarily driven by a coast-wise gradient of precipitation and evapotranspiration.
\end{abstract}

Keywords: Holocene; coastal Texas; pollen; vegetation; arboreal; Gulf of Mexico

\title{
1. Introduction
}

A major challenge in interpreting earth's history is understanding how climate has changed in the past. Understanding these changes is important for placing present and future climate change into context. Coastal regions are both densely populated and susceptible to the negative effects of 
44 these changes, particularly as they relate to sea-level rise and increasing strength of tropical 45 cyclones (Emanuel, 2005; Knutson et al., 2010; Törnqvist and Hijma, 2012).

46 The extensive Texas coastline is characterized by a large precipitation across the region,

47 making it vulnerable to climate variability. Yet, relatively few studies have documented the climate

48 and vegetative change of the region through the Holocene. This study aims to fill this gap; we

49 examine the record of coastal marine and terrestrial palynoflora, create a record of coastal

50 vegetative change through the Holocene, and finally examine whether the climate histories

51 available for central and western Texas are also reflective of coastal Texas climate.

52 The modern mean annual precipitation gradient along the coast ranges from 50 to $150 \mathrm{~cm} / \mathrm{yr}$

53 from north to south (Fig. 1), while temperatures vary little across the region. Given this strong

54 precipitation gradient, the region is sensitive to climate change and associated changes in coastal 55 ecosystems (Osland et al., 2014; Gabler et al., 2017). Holocene paleoclimate records for the region 56 are sparse, but reveal shifts between cold-wet and warm-dry conditions over millennial time scales

57 (Toomey et al., 1993; Humphrey and Ferring, 1994; Wilkins and Currey, 1999; Nordt et al., 2002)

58 that are believed to be driven by large scale climate forcing mechanisms (e.g. North American 59 Monsoon; Atlantic Multidecadal Oscillation, and El Nino-Southern Oscillation) (Buzas-Stephens 60 et al., 2014; Livsey et al., 2016). Records from central and south Texas suggest that the early 61 Holocene was dominated by cool/wet conditions, followed by warm dry conditions of the mid62 Holocene Climate Optimum, and a shift to higher frequency changes during the late Holocene 63 (Humphrey and Ferring, 1994; Nordt et al., 1994; Russ et al., 2000; Nordt et al., 2002; Buzas64 Stephens et al., 2014). However, the actual duration and magnitude of these climate changes 65 remains uncertain, especially for east Texas, so the potential climate forcing mechanisms remains 
66 uncertain. Thus, the value of the paleoclimate record for testing and refining climate models is

67 limited.

68 This study uses subaqueous cores, which both eliminate the palynomorph preservation

69 problems of coastal Texas and have the added benefit of containing both terrestrial (pollen) and

70 marine (dinoflagellate) palynomorphs. Samples come from sedimentary records obtained from 3

71 cores collected from subaqueous bayhead deltas and associated upper bay deposits in Corpus

72 Christi Bay (central coast) and Trinity Bay (eastern coast). Both bays exhibit significant changes

73 in paleo-environments throughout the Holocene, but the cause of these changes (sea-level,

74 climate change or changes in valley geomorphology which influenced bay flooding history) have

75 remained uncertain. We rely on results from detailed seismic and sedimentological analyses of

76 these and other bays of the western Gulf Coast region (Galveston estuary complex, Matagorda

77 Bay, Sabine Lake, Calcasieu Lake, Corpus Christi Bay, and Copano Bay; Anderson et al., 2008;

78 Maddox et al., 2008; Milliken, 2008a; Simms et al., 2008; Troiani et al., 2011) to address the

79 potential causes of environmental changes observed in these bays during the Holocene, and to

80 investigate likely forcing mechanisms for climate change in the region.

81

82 2. Study Areas

$83 \quad 2.1$ Physical attributes

84 Corpus Christi Bay is a moderate-sized bay located within Texas' central coast with a surface

85 area of roughly $434 \mathrm{~km}^{2}$ (Fig. 2A). The bay is a shallow estuary, with an average a depth of 3 to 4

$86 \mathrm{~m}$ (Simms et al., 2008). Average subsidence rates for this region are less than $0.05 \mathrm{~mm} / \mathrm{yr}$ (Paine,

87 1993; Simms et al., 2013). The bay is fed water and sediment by the Nueces River. It provided 6.3

$88 \times 10^{8} \mathrm{~m}^{3} \mathrm{yr}^{-1}$ of freshwater (Henley and Rauschuber, 1981; Mannino and Montagna, 1996; 
89 Wermund, 1996) and 750,000 tons $\mathrm{yr}^{-1}$ of sediment before installation of Nueces basin dams 90 (constructed in 1958 and 1982) (Shepard, 1953; Shepard, 1955; Montagna et al., 2002). The river 91 is $500 \mathrm{~km}$ in length and has a drainage area of 43,502 $\mathrm{km}^{2}$ (Hudson and Heitmuller, 2008). Mustang 92 Island separates Corpus Christi Bay from Gulf of Mexico waters, and has been stable since 7.5 93 ka (Morton and McGowen, 1980; Simms et al., 2006; Simms et al., 2008; Ferguson et al., in press).

94 Corpus Christi Bay's proximity to both semiarid and subhumid climatic zones makes it an ideal 95 location for a palynological study (Fig. 1). Since this area serves as the boundary between these 96 climate zones, even a small climatic change would cause a shift in vegetation, and in turn be 97 preserved in the palynological record.

98 Trinity Bay is located along Texas' northern coastal plain and is one of the five bays that 99 comprise the Galveston estuary complex (Fig. 2C). This complex averages 2-3 $\mathrm{m}$ in depth 100 (Anderson et al., 2008), and has more than twice the amount of subsidence seen in Corpus Christi 101 Bay (0.13 mm/yr) (Paine, 1993; Simms et al., 2013). Trinity Bay is fed freshwater by the Trinity 102 River with a mean daily discharge rate of $395 \mathrm{~m}^{3} \mathrm{~s}^{-1}$ and a combined upper and lower watershed 103 area of 84,500 $\mathrm{km}^{2}$ (Lester et al., 2002; Wen et al., 2008). The Trinity River has been impounded 104 upstream by the U.S. Army Corps of Engineers at Lake Livingston Dam since 1968 serving as 105 major water source for Houston, TX (Traverse, 1990). Galveston Island and Bolivar Peninsula 106 have separated the Galveston estuary complex from the Gulf of Mexico since 5.5 ka and 2.5 ka, 107 respectively (Anderson et al., 2008; Rodriguez et al., 2004). Marine waters currently flow partially 108 through the $3 \mathrm{~km}$ wide Bolivar Roads inlet, located between the barrier island and spit (Anderson 109 et al., 2008; Rodriguez et al., 2004). Trinity Bay is on the border between subtropical Prairie 110 Parkland Province and Southern Mixed Forest Province, making it also potentially sensitive to 111 shifts in vegetation. 


\subsection{Holocene flooding events}

114 Both bays occupy incised valleys formed during the fall in sea-level between 120 and 20

115 thousand years before present (ka) (Rodriguez et al., 2004; Simms et al., 2006; Anderson et al., 116 2008; Simkins et al., 2012). The evolution of the modern bays spans much of the Holocene, from

$117 \sim 9.5$ ka to present (Anderson et al., 2008; Simms et al., 2008). Throughout the Holocene, the 118 average rate of sea-level rise in the western Gulf of Mexico declined, from $4.2 \mathrm{~mm} / \mathrm{yr}$ in the early 119 Holocene to $1.4 \mathrm{~mm} / \mathrm{yr}$ in the mid-Holocene and $0.4 \mathrm{~mm} / \mathrm{yr}$ in the late Holocene (Milliken et al., 120 2008b). The evolution of the bays of the western Gulf was characterized by punctuated episodes 121 of change when environments stepped landward (Rodriguez et al., 2005; Anderson et al., 2008;

122 Simms et al., 2008). Some of these flooding events appear to have occurred contemporaneously 123 across the region and were interpreted as having been caused by episodes of accelerated sea-level 124 rise (Milliken, 2008b; Rodriguez et al., 2010; Anderson et al., 2014). Other flooding events were 125 more localized, effecting only one or two bays, and were associated with changes in the antecedent 126 topography of the incised valleys occupied by the different bays that resulted in variable flooding

127 histories (Rodriguez et al., 2005). More specifically, these flooding events were caused by 128 accelerated flooding of broad fluvial terraces along valley margins (Rodriguez et al., 2005). The 129 remaining flooding surfaces were attributed to reductions in sediment supply to the bays in 130 response to climate change, in particular reduced precipitation and fluvial discharge (Anderson et 131 al., 2008; Simms et al., 2008). However, direct evidence for these climate changes remains limited. 132 The earliest known flooding event and occupation of the modern bays occurred around 9.6 ka, 133 and was followed by the larger $8.2 \mathrm{ka}$ sea-level rise event caused by the drainage of glacial Lake 134 Agassiz-Ojibway (Rodriguez et al., 2010; Simms et al., 2010; Ferguson et al., in press). Several 
135 other flooding events have occurred in these bays during the mid- to late Holocene. This includes

136 a 7.7- 7.4 ka flooding event in Trinity Bay, which is tentatively interpreted as resulting from a

137 decrease in sediment supply to the bay (Anderson et al., 2008). Corpus Christi Bay experienced

138 more recent flooding events at $5.4 \mathrm{ka}$, and at $3.6 \mathrm{ka}$ that are also believed to have been caused by

139 a decrease in sediment supply (Simms et al., 2008; Troiani et al., 2011).

$141 \quad 2.3$ Modern coastal vegetation and habitat

142 Southern to central Texas upland extant vegetation is dominated by a variety of grasses

143 (Poaceae) as well as a variety of coastal scrub species indicative of arid coastal environments. Due

144 to southern Texas' aridity, bottomland hardwood forests (Carya aquatica, Carya texana, Ulmus

145 crassifolia, Quercus laurifolia, Liqiudambar styraciflua, Nyssa sylvatica), and swamp forests

146 (Quercus nigra, Nyssa biflora, Taxodium distichum, Salix nigra) are not common in this area and

147 are restricted to river floodplains (Hupp and Osterkamp, 1996).

148 The Strand Plain/Chenier Plain of Texas' eastern shoreline is home to the coastal live oak

149 population (Quercus virginiana) (Williams et al., 1999). This species is the most common on

150 Texas' forested barrier islands (or strand environments), on topographic highs, as well as the

151 eastern shoreline (Shaw et al., 1980; Williams et al., 1999). Carya cordiformis, Juglans nigra, and

152 Ulmus americana are restricted to fluvial floodplains and terraces (Hupp and Osterkamp, 1996).

153 Eastern Texas' upland vegetation consists of a variety of grasses (Poaceae) and coastal scrub

154 species like the southern cattail (Typha domingensis), which are indicative of moist coastal

155 environments (Williams et al., 1999).

156

$157 \quad 2.4$ Previous palynological studies 
Although the Gulf of Mexico is one of the most well-studied basins in the world, most of the

159 focus has been on oil exploration or on seismic and sedimentological facies models. Rarely has

160 the intent of these studies been to characterize the Holocene climatic record of coastal Texas. Of

161 those studies that discuss Holocene vegetation change, the majority focus on either the Mississippi

162 River Delta (Törnqvist and Hijma, 2012), the Edwards Plateau (Cooke et al., 2003), or central

163 Florida (Grimm et al., 2006; Huang et al., 2006; Donders, 2014), leaving an absence of insight to

164 western Gulf of Mexico climate in the Texas region. The strong precipitation gradient along the

165 northwestern Gulf Coast results in a diverse coastal vegetation assemblage (Longley, 1995;

166 Williams et al., 1999). Differences in precipitation and evapotranspiration have traditionally

167 defined four different climatic regions, ranging from humid near the Louisiana border to semiarid

168 along the coast and to the Mexican border (Thornthwaite, 1948; Williams et al., 1999) (Fig. 1).

169 Less than forty palynological studies of Quaternary Texas deposits have been published since

170 the emergence of the discipline in the 1940s. Many of these studies are old in the context of modern

171 analytical techniques (Potzger and Tharp, 1947; Potzger and Tharp, 1954), frequently omitting or

172 broadly estimating age control and pre-dating the standardization of palynological processing. The

173 first Texas palynological studies between the '40s and "50s pre-dated widespread conventional

174 radiocarbon dating and focused on peat bog sediments within the interior of the state (Potzger and

175 Tharp, 1943; Potzger and Tharp, 1947; Potzger and Tharp, 1954). The presence of boreal conifers

176 (Picea glauca and Abies balsamea) in Patschze Bog provided early evidence for the southern limit

177 of what are now Canadian conifers, and thus dramatically cooler climate (Potzger and Tharp,

178 1943). In a subsequent study, Potzger and Tharp (1947) proposed a four-stage climate sequence

179 for central Texas following the last glacial maximum. According to the authors, the sequence

180 begins with the presence of spruce and fir (cool-moist climate), giving way to a variety of grasses 
181 and oaks (warm-dry period), then an emergence of alder and chestnut (warm-moist climate), and

182 lastly a hickory and oak vegetation (warm-dry climate) (Potzger and Tharp, 1954). However, the

183 lack of a robust geochronology in this early work limits its usefulness, especially in a modern

184 context.

185 Graham and Heimsch (1960) included a single radiocarbon date of 7,280 \pm 350 yr for their

186 central Texas study, and did not agree with the Potzger and Tharp (1954) climate sequence. Rather

187 than four distinct stages, they interpreted a more simplistic climatic history of cooler and wetter

188 conditions at around $12.5 \mathrm{ka}$, transitioning slowly to today's warm-dry climate in central Texas

189 (Graham and Heimsch, 1960). A subsequent pollen analysis of nearby Hershop Bog with better

190 age control shows the same gradual warming and drying since the early Holocene with decreasing

191 arboreal vegetation (excluding Quercus) and an increasing amount of Poaceae and later Asteraceae

192 (Graham and Heimsch, 1960).

193 Hafsten (1961) examined a playa lake in western Texas and placed several radiocarbon-based 194 age constraints to Potzger and Tharp's (1947; 1954) proposed 4-stage climate sequence. According 195 to Hafsten (1961), at about 30 ka grasslands were present in west Texas and were replaced between 196 22.5-14 ka by conifer forests as climate cooled. Between 14 and $10 \mathrm{ka}$, a transitional period 197 occurred with conifer forests being replaced by grasslands and some small shrubs. During the final 198 stage from 10 ka to today, grasslands once again dominate the landscape in the lower elevations 199 of the western region.

200 Several other palynological studies were completed following these first works (Bryant and 201 Shafer, 1977; Hall, 1985; Holloway et al., 1987; Bousman, 1998), all of which studied the various 202 peat bogs, lakes, and archaeological sites in central and western Texas. Eastern Texas and its 203 associated coastal plains have largely been ignored due to the scarcity of sites promoting 
204 palynological preservation. Palynomorph preservation is generally poor due to a combination of 205 factors including high microbial activity in leaf litter on forest floors, sporopollenin damage caused

206 by the constant drying and wetting of soil, and soil oxidation (Bryant and Holloway, 1985).

207 However, several of these later studies (McAndrews and Larson, 1966; Bryant, 1977) commonly

208 provide brief climatic records, as they primarily focus on specific anthropological questions, and

209 are based on cave samples or other samples that produce a skewed vegetation record, such as

210 human coprolites (Williams-Dean and Bryant, 1975) or rat middens (Van Devender and Riskind,

211 1979). Indeed, there are only a handful of studies with reasonable age constraints, and therefore

212 relevant to Texas' Holocene climate history (Graham and Heimsch, 1960; Albert, 1981; Holloway

213 and Bryant, 1984; Bousman, 1998), without a clear consensus shared among them.

214 Here we provide a new record of Holocene climate for eastern Texas, based upon three

215 subaqueous bay floor cores containing well-preserved palynomorphs and supported by an

216 extensive modern radiocarbon geochronology and tied to in-depth seismic and sedimentological

217 analyses of the Texas coast (Anderson et al., 2008; Simms et al., 2008).

\section{3. Materials and methods}

2203.1 Sampling and radiocarbon age model

221 Drill core CCB02-01 from Corpus Christi Bay was selected for palynological analysis because

222 it contains fine-grained (silt) central-upper bay sediments where sedimentary facies have remained

223 relatively unchanged since approximately 7,500 years (Fig. 2; Simms et al., 2008). The site was

224 cored to a depth of 21 meters. Nine radiocarbon dates from Simms et al. (2008) provide our basis

225 for age control. Sixty-eight samples were collected for palynological analysis with samples

226 occurring at 10 to $20 \mathrm{~cm}$ intervals depending on sediment availability within the archived core. 
227 Two drill cores from Trinity Bay were selected for palynological analysis (TBHD-5-1 and

228 TV99-3 (Fig. 2). Six radiocarbon dates for core TBHD-5-1 and four radiocarbon dates for core

229 TV99-3 provide age control (Fig. 3; Table 1). Two additional radiocarbon samples from core

230 TBHD-5-1 and three from TV99-3 were sent to UC Irvine Keck Carbon Cycle AMS Facility to

231 help further constrain the late Holocene ages (Table 1).

232 All radiocarbon ages were calibrated using Marine13 (Reimer et al., 2013) and a basin-wide 233 reservoir correction of 300 years was applied as suggested in Törnqvist et al. (2015). An age model

234 was produced for each core using the Bchron package for R (Haslett and Parnell, 2008; Parnell et 235 al., 2008). Dates within the text and figures are reported at the Bchron 50\% quantile. Output of the 236 Bchron model quantiles $2.5 \%, 50 \%$, and $97.5 \%$ are provided in Table $\mathrm{S} 1$.

2383.2 Palynological analysis

239 Sediment samples were chemically processed by Global GeoLab Limited following standard 240 palynological laboratory methods (Brown, 2008). Dry sample weights were recorded before

241 processing, with an average of 10 grams used per sample. Lastly, a Lycopodium spores tablet with

242 a known amount was added in order to determine palynomorph concentration values

243 (palynomorph/gram). A minimum of 300 known in-situ palynomorphs (pollen, spores, and

244 dinoflagellate cysts) were counted when available for each sample to ensure accurate paleo245 environmental representation.

2473.3 Statistical analyses

248 Statistical analyses were used in combination with individual core age-models to determine the 249 potential timing of shifts in paleo-environment or climate. Constrained cluster analysis using Bray- 
250 Curtis similarity and correspondence analysis (CA), both based on raw abundance data, were used

251 to examine changes in pollen and spore assemblages through time within each core. Similarity

252 Percentage analysis (SIMPER) based on the Bray-Curtis similarity was achieved to determine

253 which taxa were controlling the clustering (Supplementary Table S2). All statistical analyses were

254 conducted using PAST v. 2.17c freeware (Hammer et al., 2001).

255

256 4. Results

257 4.1 Age models

258 Corpus Christi Bay core CCB02-01 uses the same age model produced by an earlier study

259 (Ferguson et al., in press). The age models for Trinity Bay's TBHD5-1 and TV-99-3 have been

260 updated and revised from their previously published versions (Anderson et al., 2008), so that the

261 three cores have similarly-derived age models and can be shown on the same age axis (Fig. 3).

262 Ages in the text and figures always refer to the Bchron 50\% quantile, and reported in thousands of

263 years before present (ka). Core CCB02-01 covers the most time, from $11.5 \mathrm{ka}$ to $1.6 \mathrm{ka}$. Our

264 sampling of TBHD5-1 spans from 4.5-1.0 ka, and core TV99-3 includes a short yet detailed look

265 into the most recent past from 1.8 ka to $0.2 \mathrm{ka}$.

266

2674.2 Palynological results

268 Twenty-three unique taxa were observed within these cores (Supplementary Table S1).

269 Common to all samples were nonarboreal taxa including low and high spine Asteraceae (mainly

270 Ambrosia and Helianthus), Chenopodium, Poaceae, and arboreal taxa such as Carya, Pinus, and

271 Quercus. The abundance of these taxa varies between cores; however, the majority of taxa are

272 shared by both bays. Absolute abundance of palynomorphs generally decreases down-core, likely 
273 due to oxidation after deposition. No clear first or last occurrence for any given taxa was found,

274 but rather a transition through time of dominance of one group versus another. Lack of reworked

275 taxa and the high quality of observed palynomorphs imply that the studied cores are representative

276 mostly of their immediately surrounding environment, and thus mostly represent their respective

277 drainage basins only to a limited extent.

278 In general, these assemblage results from Trinity Bay and Corpus Christi Bay show a trend of 279 herbaceous nonarboreal dominated assemblages in the early to mid-Holocene transitioning into 280 arboreal dominated assemblages in the late Holocene (Fig. 4). The transition within Trinity Bay 281 occurs much more rapidly. Two noteworthy peaks in Carya (hickory tree, pecan tree) are noted at $2824.1 \mathrm{ka}$ and $2.2 \mathrm{ka}$ in Corpus Christi Bay. Overall, Corpus Christi Bay has much more nonarboreal 283 then arboreal pollen throughout the studied interval (average relative abundance of nonarboreal is $28472 \%$ ) while Trinity Bay has been clearly more humid throughout the time interval studied with 285 arboreal pollen dominating with average values of $70 \%$ (i.e., average relative abundance of 286 nonarboreal of only 30\%) (Fig. 5). Statistical results further explore this palynological trend and 287 provide better constraint on the timing of observed changes.

2894.3 Statistical results

290 Cluster analysis (Supplementary Figure 1) followed by correspondence analysis were 291 performed on complete pollen assemblages within each core (Fig. 6A-C), as well on just the 11 292 taxa common to each core. The all-taxon and 11-taxon analyses for each separate core produced 293 essentially similar results, as the 11 common taxa together control more than $80 \%$ of among294 cluster differences. These 11 major taxa are Asteraceae, Chenopodium, Poaceae, Ilex, 295 Onagraceae, Acer, Alnus, Carya, Juglans, Pinus, and Quercus. 
Four distinct sample clusters (Fig. 6A, colored polygons) are present in both CCB02-01 and

297 TBHD5-1; TV99-3 has the fewest samples, and only produced three clusters. The clusters

298 correspond to different age ranges within each core, with no inversions or mixing. The same

299 observational trend seen within the palynological results (Fig. 4) is also seen within these clusters:

300 deeper samples are dominated by herbaceous and nonarboreal taxa, which transition to mostly

301 arboreal taxa towards the top of the cores. In addition, the clusters provide important age control

302 for each transitional event. At Corpus Christi, the first cluster occurs from 11.2 to $10.1 \mathrm{ka}$, and is

303 characterized by the strongest representation of herbaceous plants with mostly Chenopodium. A

304 second cluster occurs from 10 to $8.4 \mathrm{ka}$; the samples included in this cluster are mainly composed

305 of herbaceous plants (Poaceae, Asteraceae) but also a variety of angiosperms (Juglans,

306 Onagraceae, and Apiaceae) and Ephedra. A unique 200 year-long cluster occurs from 8.4 until 8.2

$307 \mathrm{ka}$. The vegetation is not extremely different in this horizon, however pollen abundance decreases

308 tremendously, while dinoflagellate cyst peaks in abundance (Fig. 5). Finally, the fourth cluster

309 represents a tree-dominated environment (Alnus, Carex, Quercus, Ulmus, Pinus and Carya) from

3108.2 ka onwards.

311 Although the interval at Trinity Bay is shorter (the last $4.9 \mathrm{ka}$ ), a similar trend towards an

312 increasingly tree-dominated environment is noted. Some minor changes allow the subdivisions of 313 the period of tree dominance into four time intervals for core TBHD5-1 (Fig. 6B). These sub314 intervals occur at the age intervals 4.9 to $4.1 \mathrm{ka}, 3.8$ to $2.0 \mathrm{ka}, 1.9$ to $1.5 \mathrm{ka}$, and 1.5 to $1.0 \mathrm{ka}$. It is 315 interesting to note that one of the markers allowing for the separation of the fourth interval is the 316 presence of Zea mays, or maize. Despite being wind-pollenated, Zea mays pollen grains are large 317 in size and density causing the grains to sink from the air quickly near the crop itself allowing for 
318 a local signal (Traverse, 2007). The presence of maize occurs in core TBHD5-1 at 1.5 ka, $1.3 \mathrm{ka}$, 319 and $1.2 \mathrm{ka}$ (one grain per interval; Table S2).

320 Core TV99-3 has three distinct palynological clusters (Fig. 6C). Between 2.8 and 2.6 ka a 321 majority of herbaceous genera (Chenopodium, Poaceae, Utrica, and Ilex) and two arboreal taxa 322 (Quercus, and Carya). From 2.5 to 1.8 ka arboreal Juglans, Galium, and Hippuris control this 323 transitional cluster. Lastly, between $1.6 \mathrm{ka}$ and $0.2 \mathrm{ka}$ Pinus (pine), Salix (willow), and Alnus 324 (alder) characterize the most recent time period. This core has more taxa as outliers than the other 325 cores because of the relatively low abundance of many of the taxa (Fig 6C).

326 The same analyses performed on a dataset including all three cores shows that samples from 327 the three cores plot amongst one another, and not within separate, core-dependent groups (Fig. 7). 328 Comparison of the first correspondence axis (CA1) resulting from the combined core analysis 329 against the CA1 resulting from the separate correspondence analysis of core CCB02-01 yields an 330 almost perfect linear relation $\left(\mathrm{R}^{2}=0.96\right)($ Fig. $8 \mathrm{~A})$; comparison with both Trinity Bay cores yields 331 an even higher $\mathrm{R}^{2}$ of 0.99 (Fig. 8B). Such congruence of the first correspondence (CA1) axis 332 between the three separate cores and the combined core analyses indicates that this axis within 333 each separate core points toward the same environmental gradient controlled by the same taxa. 334 This makes it possible for direct comparisons of the environmental changes seen within the three 335 cores, and strongly suggests that these changes were driven by allogenic factors influencing both 336 bays, rather than separate autogenic forcings.

337 Based on the sample groups resulting from the cluster analyses of each separate core, SIMPER 338 analyses enable the identification of the taxa that most contribute to cluster's differentiation - i.e., 339 the taxa that most strongly vary in abundance from one cluster to another (Supplementary Table 340 S2). At Corpus Christi Bay, contrasting the two oldest samples groups D and C (Fig. 6A: red and 
341 purple clusters) shows that $78 \%$ of the overall average difference (OAD) between these two

342 clusters is controlled by changes in abundances of Chenopodium, Asteraceae, Quercus, and

343 Poaceae (in order of percent contribution; Table S3). Contrasting the second (C) and third (B)

344 samples groups shows that $72 \%$ of their OAD is driven by Asteraceae, Chenopodium, Quercus,

345 and Poaceae. Last, contrasting the most recent sample groups B and A shows $82 \%$ of their OAD

346 is controlled by changes in abundances of Pinus, Quercus, Chenopodium, and Asteraceae. In

347 Trinity Bay these same taxa are involved at similar percentages of contribution to between-group

$348 \mathrm{OAD}$, indicating similar changes in vegetational habitats from one cluster to another. Thus, the

349 main difference between the bays is based not upon the individual clusters of vegetation, but rather

350 the timing and appearance of these clusters (Fig. 6).

351

352 5. Discussion

3535.1 Vegetational Holocene evolution

354 Factors such as soil type, water or soil $\mathrm{pH}$, flooding frequency, light intensity, nutrients, and 355 anthropogenic disturbances can produce different community structures composed of different 356 plants or mixtures of plants with or without a climatic forcing (Wharton et al., 1982). This said, 357 clear trends are observed and statistically validated in the studied cores. Cores from both bays 358 show a vegetational trend from nonarboreal-dominated to arboreal-dominated vegetation through 359 the Holocene, the change being more pronounced in Trinity Bay (Fig. 5). Assemblages determined 360 from cluster, correspondence, and SIMPER analyses show little variation between the two bays 361 despite their geographic separation. Overall, the higher relative abundance of trees at Trinity Bay 362 confirms that this area was more humid than Corpus Christi Bay throughout the time interval 363 covered by all three cores. An exception occurs at the base of the observed Trinity Bay record, 
364 where arboreal pollen is close to $15 \%$; it's unclear if this suggests that mid-Holocene Trinity Bay 365 was much drier than it is now, or if this is simply because the Trinity bayhead delta was further 366 away from the cored locations at this point in time, which reduced input of arboreal pollen.

367 Out of the dominant taxa observed in this study, many are tolerant of infrequent flooding of 368 varying duration. The most tolerant taxon is Taxodium distichum (common in shallow waters that 369 experience frequent drying periods between floods), while Carya and Juglans are unable to survive 370 more than a few days of flooding at a time. Thus, all most likely represent low-lying forest cover 371 types with Taxodium in lower sections, and exclude full marsh or backswamp locales. Most 372 Quercus species currently living along Texas' coast can only tolerate minimal to occasional 373 flooding (Quercus alba, Q. fusiformis, Q. macrocarpa) (Moulton et al., 1997). Other species ( $Q$. 374 nigra, $Q$. phellos, $Q$. lyrata) are slightly more tolerant of flooding and typically occur along river 375 floodplains at higher elevations than Taxodium distichum (Moulton et al., 1997). However, 376 Quercus pollen is difficult to reliably isolate to the species level with a light microscope and 377 therefore it is important to use other genera to help understand a habitat's tolerance to flooding 378 and typical amount of water saturation. Carya is commonly associated with Juglans, Fraxinus, 379 Celtis, and Ulmus along shallow marginal swamps and floodplains of the Gulf Coast. Carya is 380 particularly common inland and is part of the riparian vegetation of the Nueces River (Vaughn 381 Bryant, pers. comm.). Thus, the peaks observed at $4.1 \mathrm{ka}$ and $2.2 \mathrm{ka}$ in Corpus Christi Bay could 382 indicate an increase in river flux; Myrica is normally an understory shrub within this community 383 (Moulton et al., 1997). The prevalence of Pinus pollen found in samples is likely a product of 384 regional pollen rain from the drainage basins' interfluvial wet pine flatlands (Moulton et al., 1997). 385 While some Pinus pollen is considered to be autochthonous, the abundance of pollen Pinus 
produces, along with its morphological ability to travel large distances, should be kept in mind

387 when determining its presence around the bays and basins they drain.

388 Herbaceous taxa are abundant, particularly in the lower sections of all the cores. Many of these

389 species are confined to open coastal habitats due to their need for full sunlight. Herbaceous plants

390 can also dominate drier environments and tundra plains, but some species of Chenopodiaceae,

391 low-lying Asteraceae, Cyperaceae, and Poaceae (for instance Spartina marsh grasses) are also 392 adapted to growing in continually wet fresh to brackish conditions, with many species able to 393 tolerate the salinity of coastal soils in return for the freedom of little to no canopy cover. The 394 occurrence, and at times dominance, of these species within some intervals indicates dominance 395 of a marsh environment.

396 In summary, the environment at both study areas evolved from a marsh-dominated environment 397 to an increasingly dense riparian canopy of trees along the rivers and bays. The trend occurs over 398 a much shorter period in Trinity Bay, as Corpus Christi Bay was transitioning away from 399 nonarboreal vegetation as much as $4 \mathrm{ka}$ earlier. The shorter record from Trinity Bay makes direct 400 comparison of these bay's coeval vegetation regimes impossible for much of the early Holocene, 401 but correspondence analysis results confirm that the clusters occurring at both bays are identical. 402 Thus, a longer record in Trinity Bay would likely only extend the base of the oldest nonarboreal403 dominated cluster, and not affect the age of the transition between clusters.

406 In Trinity Bay, Chenopodium and Asteraceae are the main vegetational component of the oldest 407 samples from 4.91-4.05 ka (TBHD5-1; Fig. 6B). The vegetational landscape began experiencing 408 more diversity around $3.83 \mathrm{ka}$, at which time a number of other nonarboreal elements such as 
Apiaceae, Onagraceae, Poaceae, and llex appear in core TBHD5-1. TV99-3's shorter record begins

410 at $2.84 \mathrm{ka}$, and mirrors the assemblages found within TBHD5-1. Alnus and Carya are important

411 arboreal components beginning at $2.04 \mathrm{ka}$, while Pinus and Juglans have the greatest influence

412 from 1.89-1.53 ka (TBHD5-1 and TV99-3). Increased fluvial discharge, frequency of flooding,

413 and associated increase in sediment delivery to Trinity Bay are thus indicated for the late Holocene.

414 This corresponds to significant growth of the Trinity bayhead delta, as documented by Anderson

415 et al. (2008), and is corroborated by the low dinoflagellate cyst concentrations seen within

416 proximal TBHD5-1 during this time, interpreted as indicating increased freshwater discharge to

417 the bay (Fig. 2; Fig. 5).

418 Dinoflagellate cyst concentrations at more distal TV99-3 were unaffected in the same way, with

419 a peak in concentrations at that location at $\sim 1.7 \mathrm{ka}$. This peak is smaller in magnitude than a peak

420 occurring at $0.8 \mathrm{ka}$ that we hypothesize is related to an established major storm (Rodriguez et al.,

421 2004; Anderson et al., 2008). Rodriguez et al. (2004) suggest that the storm cut deeply into the

422 Bolivar Peninsula and resulted in a reduction of the Galveston-Bolivar barrier complex as an

423 effective salinity barrier. Thus, perhaps the $1.7 \mathrm{ka}$ event is similarly storm-related.

424 Finally, a major shift to oak-pine woodland vegetation occurred around 1.49 ka based on our

425 correspondence analysis. Pinus and Quercus are the major overall contributors to the pollen

426 assemblage in this recent section. This assemblage also includes Zea mays, which is an indication

427 of early agriculture. Thus, this assemblage is likely either indicative of, or coincides with,

428 anthropological influence rather than a climatic change. Native American activity in coastal Texas

429 is known for that time period from other records (Ricklis, 2004), and is thought to have occurred

430 as far back as $9.5 \mathrm{ka}$ (Warny et al., 2012). 
431 The Corpus Christi Bay palynological record generally shows a similar overall vegetational 432 evolution as observed in Trinity Bay, but this evolution occurred much earlier. In general, Corpus 433 Christi Bay has an overall lower arboreal component than Trinity Bay, but its transition to 434 dominance of that component occurred up to 4 ka sooner. Similar to Trinity Bay core TBHD5-1, 435 Corpus Christi Bay core CCB02-01 had enough within-core differences allowing for the 436 subdivision of four vegetation assemblages through time. As stated previously, these assemblages 437 are statistically identical to the assemblages seen later in Trinity Bay (TBHD5-1 and TV99-3). 438 Chenopodium primarily controls variability in the earliest part of the Corpus Christi Bay record 439 from 11.2-10.1 ka. More herbaceous elements (Asteraceae, Apiaceae, Onagraceae, and Poaceae) 440 are added to the assemblage starting from 10-8.4 ka (Fig. 4a). From 8.4-8.2 ka (Fig. 4a, blue 441 cluster), a brief period of time is isolated by cluster analysis (Supplementary Figure 1), likely due 442 to the low pollen yield recovered during this time. This interval is also marked by a flooding 443 surface (FS2) expressed in seismic records and cores from the bay (Simms et al., 2008; Rodriguez 444 et al., 2010). Ferguson et al. (in press) observed a marked increase in dinoflagellate cysts during 445 that same interval of time with an assemblage dominated by Polysphaeridium zoharyi, a 446 dinoflagellate species requiring marine salinity. They postulated that this prominent and sudden 447 increase corresponds to the overtopping of Mustang Island during the $\sim 8.2$ ka northern hemisphere 448 ice sheet mass wasting event and associated abrupt sea-level rise (the only major perturbation in 449 the $\delta^{18} \mathrm{O}$ curve for the Holocene, Fig. 5). That interval is not marked by notably different 450 vegetation, so it is indeed likely that the sedimentation at that time was controlled by a punctuated 451 sea-level rise event, rather than a regional climatic event. After this time, from 8.2-1.6 ka, the 452 increasing abundance of trees is the main element controlling the clustering. This is coincident 
453 with the progradation of the delta after the major flooding of the delta during the 8.2 ka event. 454 Pinus, Quercus, Acer, Alnus, Carya, Ulmus, and Celtis all contribute to the clustering at this time.

455 Simms et al. (2008) noted two other potential flooding events at $5.4 \mathrm{ka}$ and $3.6 \mathrm{ka}$ (revised ages

456 of FS3 and FS4 from Ferguson et al., in press age model). At 5.4 ka, our palynological record 457 indicates that this time interval marks the beginning of an increase in arboreal pollen, along with 458 a marine event marked by an increase of dinoflagellate cysts (Fig. 5) (Ferguson et al., in press). 459 Simms et al. (2008) believed that this horizon was either due to a climatic change towards warmer 460 and drier conditions or the flooding of a relict Nueces fluvial terrace. We suggest that the coupled 461 increase of dinoflagellates and arboreal pollen indicates that this event was a result of flooding of 462 relict terraces.

463 At $3.6 \mathrm{ka}$, our records from Corpus Christi Bay show arboreal pollen accounts for $50 \%$ of the 464 palynological assemblage, well above the core average (Fig. 5). Simms et al. (2008) hypothesized 465 that this horizon might have been associated with a decrease in sediment delivery due to a climatic 466 drying event. Based on the palynological data, the 3.6 ka event was marked by a climate shift but 467 was likely a return to more mesic climatic conditions, which would have increased tree cover, 468 stabilized the landscape, and a decreased fluvial output/sediment supply. This shift to more mesic 469 condition around $3 \mathrm{ka}$ is also shown as a decrease in more salt tolerant foraminifera within Baffin 470 Bay (Buzas-Stephens et al., 2014).

471

\section{6. Conclusions}

473 Our results show that the Holocene coastal environments of central Texas began transitioning

474 from herbaceous (nonarboreal) dominated vegetation to arboreal dominated vegetation as early as $475 \sim 8.4 \mathrm{ka}$. This is indicative of a transition to less aridity as coastal rivers and bays evolved from a 
476 marsh-dominated environment to an increasingly dense riparian canopy of trees. Lack of reworked

477 palynomorphs indicate that our samples are indicative of local vegetation, rather than regional or

478 basin-scale vegetation changes.

479 In Corpus Christi Bay, pollen indicates potentially increased discharge from Nueces river at 4.1

$480 \mathrm{ka}$ and $2.2 \mathrm{ka}$. Marine flooding events are seen at 8.2 ka, $5.4 \mathrm{ka}$, and $3.6 \mathrm{ka}$. As suggested by

481 Ferguson et al. (in press), the $8.2 \mathrm{ka}$ event is associated with the rapid draining of Lake Agassiz-

482 Ojibway. Simms et al. (2008, FS2) suggested that the 5.4 ka event was the flooding of relict fluvial

483 terraces, which we support with an associated increase in dinoflagellate concentrations likely

484 related to the areal increase in warm brackish surface waters. At about 3.6 ka there was an increase

485 in mesic conditions, indicated by a large abundance of arboreal pollen. This was coincident with

486 a slight increase in dinoflagellate cysts indicating low freshwater input into the bay. This event

487 corresponds to a flooding surface observed by Simms et al. (2008, FS4) which they interpret as

488 the product of low sediment delivery to the bay.

489 Flooding events in Trinity Bay were observed at 1.7, 1.2, and $0.8 \mathrm{ka}$; the $0.8 \mathrm{ka}$ event is likely

490 related evidence of a major storm that Rodriguez et al. (2004) suggest cut through the Bolivar

491 Peninsula at that time. The 1.7 and $1.2 \mathrm{ka}$ events are smaller in magnitude, and may also be storm-

492 related. Finally, the most recent vegetation assemblage includes Zea mays, indicative of native

493 American activity around Trinity Bay starting at least $1.49 \mathrm{ka}$.

494 Our record from Corpus Christi Bay shows a gradual change during the middle Holocene

495 Climate Optimum, which appears to have been a significant climate event based on other 496 paleoclimate records (Toomey, 1993; Humphrey and Ferring, 1994; Nordt et al., 1994; Nordt et

497 al., 2002). We see no evidence that the vegetation assemblage of coastal Texas changed in direct

498 response to the Climate Optimum. There is subtle, but not statistically significant, evidence of the 
more variable climate oscillations for the late Holocene. But, our data indicates that Coastal Texas'

500 climate operated independently from the central Texas regions previously studied. Both bays

501 underwent a nonarboreal to arboreal environmental change, starting around 8.4 ka in Corpus

502 Christi Bay, but not until 5 ka in Trinity Bay. The late Holocene record for Trinity Bay shows a

503 greater dominance of arboreal pollen than in Corpus Christi Bay for the same time interval, likely

504 due to its greater precipitation and lower evapotranspiration rates.

505

\section{Acknowledgements}

507 This project was funded by a curatorial assistantship from the LSU Museum of Natural Science.

508 Sample processing was funded by The Center for Excellence in Palynology (CENEX), Louisiana

509 State University. Thanks are extended to Crawford White for valuable discussion and assistance

510 with this study.

\section{References}

Albert, L. E., 1981, Ferndale bog and natural lake: five thousand years of environmental change in southeastern Oklahoma.

Anderson, J. B., Rodriguez, A. B., Milliken, K. T., and Taviani, M., 2008, The Holocene evolution of the Galveston estuary complex, Texas: Evidence for rapid change in estuarine environments: Geol. Soc. Spec. Pap., v. 443, p. 89-104.

Anderson, J. B., Wallace, D. J., Simms, A. R., Rodriguez, A. B., and Milliken, K. T., 2014, Variable response of coastal environments of the northwestern Gulf of Mexico to sealevel rise and climate change: Implications for future change: Mar. Geol., v. 352, p. 348366.

Bousman, C. B., 1998, Paleoenvironmental change in central Texas: the palynological evidence: The Plains Anthropologist, p. 201-219.

Brown, C. A., 2008, Palynological techniques, American Association of Stratigraphic Palynologists Foundation.

Bryant, V. M., 1977, A 16,000 year pollen record of vegetational change in central Texas: Palynology, p. 143-156.

Bryant, V. M., and Holloway, R. G., 1985, A late-Quaternary paleoenvironmental record of Texas: an overview of the pollen evidence: Pollen record of late Quaternary North 
American sediments: Calgary, Canada, American Association of Stratigraphic Palynologists, p. 39-70.

Bryant, V. M., and Shafer, H. J., 1977, Late Quaternary Paleoenvironment of Texas: a Model for Archeologist: Bulletin of the Texas Archaeological Society, v. 48, p. 1-25.

Buzas-Stephens, P., Livsey, D. N., Simms, A. R., and Buzas, M. A., 2014, Estuarine foraminifera record Holocene stratigraphic changes and Holocene climate changes in ENSO and the North American monsoon: Baffin Bay, Texas: Palaeogeography, Palaeoclimatology, Palaeoecology, v. 404, p. 44-56.

Cooke, M. J., Stern, L. A., Banner, J. L., Mack, L. E., Stafford, T. W., and Toomey, R. S., 2003, Precise timing and rate of massive late Quaternary soil denudation: Geology, v. 31, no. 10, p. 853-856.

Donders, T. H., 2014, Middle Holocene humidity increase in Florida: Climate or sea-level?: Quaternary Science Reviews, v. 103, p. 170-174.

Emanuel, K., 2005, Increasing destructiveness of tropical cyclones over the past 30 years: Nature, v. 436, no. 7051, p. 686-688.

Ferguson, S., Warny, S., Anderson, J., Simms, A. R., and White, C., in press, Breaching of Mustang Island in response to the $8.2 \mathrm{ka}$ sea-level event and impact on Corpus Christi Bay, Gulf of Mexico: implications for future coastal change: The Holocene: in press.

Gabler, C. A., Osland, M. J., Grace, J. B., Stagg, C. L., Day, R. H., Hartley, S. B., Enwright, N. M., From, A. S., McCoy, M. L., and McLeod, J. L., 2017, Macroclimatic change expected to transform coastal wetland ecosystems this century: Nature Climate Change, v. 7, no. 2, p. 142-147.

Graham, A., and Heimsch, C., 1960, Pollen studies of some Texas peat deposits: Ecology, v. 41, no. 4, p. 751-763.

Grimm, E. C., Watts, W. A., Jacobson, G. L., Hansen, B. C. S., Almquist, H. R., and Dieffenbacher-Krall, A. C., 2006, Evidence for warm wet Heinrich events in Florida: Quaternary Science Reviews, v. 25, no. 17, p. 2197-2211.

Hafsten, U., 1961, Pleistocene development of vegetation and climate in the southern High Plains as evidenced by pollen analysis: Paleoecology of the Llano Estacado, p. 59-91.

Hall, S. A., 1985, Quaternary pollen analysis and vegetational history of the Southwest: Pollen records of late-Quaternary North American sediments, p. 95-123.

Hammer, Ø., Harper, D., and Ryan, P., 2001, PAST: Paleontological Statistics Software Package for Education and Data Analysis Palaeontol. Electronica 4: 1-9.

Haslett, J., and Parnell, A., 2008, A simple monotone process with application to radiocarbondated depth chronologies: Journal of the Royal Statistical Society: Series C (Applied Statistics), v. 57, no. 4, p. 399-418.

Henley, D. E., and Rauschuber, D. G., 1981, Freshwater Needs of Fish and Wildlife Resources in the Nueces-Corpus Christi Bay Area, Texas: A Literature Synthesis: Washington, D.C., U.S. Fish and Wildlife Service, Office of Biological Services Report FWS/OBS-80/10.

Holloway, R., Raab, L. M., and Stuckenrath, R., 1987, Pollen analysis of Late-Holocene sediments from a central Texas bog: The Texas journal of science (USA).

Holloway, R. G., and Bryant, V. M., 1984, Picea glauca pollen from Late Glacial deposits in central Texas: Palynology, v. 8, no. 1, p. 21-32.

Huang, Y., Shuman, B., Wang, Y., Webb, T., Grimm, E. C., and Jacobson, G. L., 2006, Climatic and environmental controls on the variation of $\mathrm{C} 3$ and $\mathrm{C} 4$ plant abundances in central 
Florida for the past 62,000 years: Palaeogeography, Palaeoclimatology, Palaeoecology, v. 237, no. 2, p. 428-435.

Hudson, P. F., and Heitmuller, F. T., 2008, Rivers and landscapes of the Texas Gulf Coastal Plain: Southwestern Geogr, v. 12, p. 90-123.

Humphrey, J. D., and Ferring, C. R., 1994, Stable isotopic evidence for latest Pleistocene and Holocene climatic change in north-central Texas: Quaternary Research, v. 41, no. 2, p. 200-213.

Hupp, C. R., and Osterkamp, W. R., 1996, Riparian vegetation and fluvial geomorphic processes: Geomorphology, v. 14, no. 4, p. 277-295.

Knutson, T. R., McBride, J. L., Chan, J., Emanuel, K., Holland, G., Landsea, C., Held, I., Kossin, J. P., Srivastava, A. K., and Sugi, M., 2010, Tropical cyclones and climate change: Nature Geoscience, v. 3, no. 3, p. 157-163.

Lester, J., Gonzalez, L. A., Sage, T., and Gallaway, A., 2002, The state of the bay: A characterization of the Galveston Bay ecosystem: Galveston Bay Estuary Program.

Longley, W. L., 1995, Estuaries, in North, G. R., Schmandt, J., and Clarkson, J., eds., The impact of global warming on Texas: a report to the Task Force on Climate Change in Texas: Austin, Texas, USA, University of Texas, p. 88-118.

Livsey, D.N., Simms, A.R., Hangsterfer, A., Nisbet, R.A., and DeWitt, R., Drought modulated by North Atlantic sea surface temperatures for the last 3,000 years along the northwestern Gulf of Mexico: Quaternary Science Reviews, v. 135, p. 54-64.

Maddox, J., Anderson, J. B., Milliken, K. T., Rodriguez, A. B., Dellapenna, T. M., and Giosan, L., 2008, The Holocene evolution of the Matagorda and Lavaca estuary complex, Texas, USA: Geological Society of America Special Papers, v. 443, p. 105-119.

Mannino, A. N., and Montagna, P. A., 1996, Fine-scale spatial variation of sediment composition and salinity in Nueces Bay of South Texas: Texas Journal of Science, v. 48, no. 1.

McAndrews, J., and Larson, D., 1966, Pollen analysis of Eagle Cave: A preliminary study of the paleoecology of the Amistad Reservoir Area, p. 178-184.

Milliken, K. L. T., 2008, Holocene sea-level history and the evolution of Sabine Lake and Calcasieu Lake; east Texas and west Louisiana, USA and the glacial retreat history of Maxwell Bay, South Shetland Islands, Antarctica: Implications for ice cap thickness, retreat, and climate change.

Milliken, K. T., Anderson, J.B., Rodriguez, A.B. , 2008b, A new composite Holocene sea-level curve for the northern Gulf of Mexico: Geol. Soc. Spec. Pap., v. 443, p. 1-11.

Montagna, P. A., Kalke, R. D., and Ritter, C., 2002, Effect of restored freshwater inflow on macrofauna and meiofauna in upper Rincon Bayou, Texas, USA: Estuaries, v. 25, no. 6, p. 1436-1447.

Morton, R. A., and McGowen, J., 1980, Modern depositional environments of the Texas coast, University of Texas at Austin, Bureau of Economic Geology.

Moulton, D. W., Dahl, T. E., and Dall, D., 1997, Texas coastal wetlands: Status and trends, mid1950's to early 1990's, US Fish and Wildlife Service, Southwestern Region.

Nordt, L. C., Boutton, T. W., Hallmark, C. T., and Waters, M. R., 1994, Late Quaternary vegetation and climate changes in central Texas based on the isotopic composition of organic carbon: Quaternary Research, v. 41, no. 1, p. 109-120.

Nordt, L. C., Boutton, T. W., Jacob, J. S., and Mandel, R. D., 2002, C4 plant productivity and climate-CO2 variations in south-central Texas during the late Quaternary: Quaternary Research, v. 58, no. 2, p. 182-188. 
Osland, M. J., Day, R. H., Larriviere, J. C., and From, A. S., 2014, Aboveground allometric models for freeze-affected black mangroves (Avicennia germinans): equations for a climate sensitive mangrove-marsh ecotone: PloS one, v. 9, no. 6, p. e99604.

Paine, J. G., 1993, Subsidence of the Texas coast: inferences from historical and late Pleistocene sea levels: Tectonophysics, v. 222, no. 3-4, p. 445-458.

Parnell, A. C., Haslett, J., Allen, J. R. M., Buck, C. E., and Huntley, B., 2008, A flexible approach to assessing synchroneity of past events using Bayesian reconstructions of sedimentation history: Quat. Sci. Rev., v. 27, no. 19-20, p. 1872-1885.

Potzger, J., and Tharp, B., 1943, Pollen record of Canadian spruce and fir from Texas bog: Science, v. 98 , no. 2557, p. 584-584.

Potzger, J. E., and Tharp, B. C., 1947, Pollen profile from a Texas bog: Ecology, v. 28, no. 3, p. 274-280.

Potzger, J. E., and Tharp, B. C., 1954, Pollen study of two bogs in Texas: Ecology, v. 35, no. 4, p. 462-466.

Reimer, P. J., Bard, E., Bayliss, A., Beck, J. W., Blackwell, P. G., Bronk Ramsey, C., Buck, C. E., Cheng, H., Edwards, R. L., and Friedrich, M., 2013, IntCal13 and Marine13 radiocarbon age calibration curves $0-50,000$ years cal BP.

Ricklis, R. A., 2004, The archeology of the Native American occupation of southeast Texas: The prehistory of Texas, p. 181-202.

Rodriguez, A. B., Anderson, J. B., Siringan, F. P., and Taviani, M., 2004, Holocene Evolution of the East Texas Coast and Inner Continental Shelf: Along-Strike Variability in Coastal Retreat Rates: Journal of Sedimentary Research, v. 74, no. 3, p. 405-421.

Rodriguez, A. B., Anderson, J. B., and Simms, A. R., 2005, Terrace inundation as an autocyclic mechanism for parasequence formation: Galveston Estuary, Texas, USA: Journal of Sedimentary Research, v. 75, no. 4, p. 608-620.

Rodriguez, A. B., Greene, D. L., Anderson, J. B., and Simms, A. R., 2008, Response of Mobile Bay and eastern Mississippi Sound, Alabama, to changes in sediment accommodation and accumulation, Special Paper 443: Response of Upper Gulf Coast Estuaries to Holocene Climate Change and Sea-Level Rise, Geological Society of America, p. 13-29.

Rodriguez, A. B., Simms, A. R., and Anderson, J. B., 2010, Bay-head deltas across the northern Gulf of Mexico back step in response to the 8.2 ka cooling event: Quat. Sci. Rev., v. 29, no. 27-28, p. 3983-3993.

Russ, J., Loyd, D. H., and Boutton, T. W., 2000, A paleoclimate reconstruction for southwestern Texas using oxalate residue from lichen as a paleoclimate proxy: Quaternary International, v. 67, no. 1, p. 29-36.

Shaw, R. B., Volman, K. C., and Smeins, F. E., 1980, Modern pollen rain and vegetation on the edwards plateau, texas: Palynology, v. 4, no. 1, p. 205-213.

Shepard, F. P., 1953, Sedimentation rates in Texas estuaries and lagoons: AAPG Bulletin, v. 37, no. 8, p. 1919-1934.

Shepard, F. P., 1955, Delta-front valleys bordering the Mississippi distributaries: Geological Society of America Bulletin, v. 66, no. 12, p. 1489-1498.

Simkins, L. M., Simms, A. R., Cruse, A. M., Troiani, T., Atekwana, E. A., Puckette, J., and Yokoyama, Y., 2012, Correlation of early and mid-Holocene events using magnetic susceptibility in estuarine cores from bays along the northwestern Gulf of Mexico: Palaeogeogr. Palaeoclimatol. Palaeoecol., v. 346-347, p. 95-107. 
Simms, A. R., Anderson, J. B., and Blum, M., 2006, Barrier-island aggradation via inlet migration: Mustang Island, Texas: Sedimentary Geol., v. 187, no. 1-2, p. 105-125.

Simms, A. R., Anderson, J. B., Rodriguez, A. B., and Taviani, M., 2008, Mechanisms controlling environmental change within an estuary: Corpus Christi Bay, Texas, USA: Geol. Soc. Spec. Pap., v. 443, p. 121-146.

Simms, A. R., Aryal, N., Miller, L., and Yokoyama, Y., 2010, The incised valley of Baffin Bay, Texas: a tale of two climates: Sedimentology, v. 57, no. 2, p. 642-669.

Simms, A.R., Anderson, J.B., DeWitt, R., Lambeck, K., and Purcell, A., 2013, Quantifying rates of coastal subsidence since the last interglacial and the role of sediment loading: Global and Planetary Change, v. 111, p. 296-308.

Thornthwaite, C. W., 1948, An approach toward a rational classification of climate: Geographical review, v. 38, no. 1, p. 55-94.

Toomey, R. S., 1993, Late Pleistocene and Holocene faunal and environmental changes at Hall's Cave, Kerr County, Texas.

Toomey, R. S., Blum, M. D., and Valastro, S., 1993, Late Quaternary climates and environments of the Edwards Plateau, Texas: Global and planetary change, v. 7, no. 4, p. 299-320.

Törnqvist, T. E., and Hijma, M. P., 2012, Links between early Holocene ice-sheet decay, sealevel rise and abrupt climate change: Nat. Geosci., v. 5, no. 9, p. 601-606.

Törnqvist, T. E., Rosenheim, B. E., Hu, P., and Fernandez, A. B., 2015, Radiocarbon dating and calibration, Handbook of Sea-Level Research, John Wiley \& Sons, Ltd, p. 347-360.

Traverse, A., 1990, Studies of pollen and spores in rivers and other bodies of water, in terms of source-vegetation and sedimentation, with special reference to Trinity River and Bay, Texas: Review of Palaeobotany and Palynology, v. 64, no. 1-4, p. 297-303.

Troiani, B., Simms, A., Dellapenna, T., Piper, E., and Yokoyama, Y., 2011, The importance of sea-level and climate change, including changing wind energy, on the evolution of a coastal estuary: Copano Bay, Texas: Marine Geology, v. 280, no. 1, p. 1-19.

Troiani, B. T., Simms, A. R., Dellapenna, T., Piper, E., and Yokoyama, Y., 2011, The importance of sea-level and climate change, including changing wind energy, on the evolution of a coastal estuary: Copano Bay, Texas: Marine Geology, v. 280, no. 1-4, p. $1-19$.

Van Devender, T. R., and Riskind, D. H., 1979, Late Pleistocene and early Holocene plant remains from Hueco Tanks State Historical Park: the development of a refugium: The Southwestern Naturalist, p. 127-140.

Warny, S., Jarzen, D. M., Evans, A., Hesp, P., and Bart, P., 2012, Environmental significance of abundant and diverse hornwort spores in a potential submerged Paleoindian site in the Gulf of Mexico: Palynology, v. 36, no. 2, p. 234-253.

Wen, L.-S., Warnken, K. W., and Santschi, P. H., 2008, The role of organic carbon, iron, and aluminium oxyhydroxides as trace metal carriers: Comparison between the Trinity River and the Trinity River Estuary (Galveston Bay, Texas): Marine Chemistry, v. 112, no. 1, p. 20-37.

Wermund, E. G., 1996, River Basin Map of Texas: Bureau of Economic Geology, Universtiy of Texas at Austin.

Wharton, C. H., Kitchens, W. M., Pendleton, E. C., and Sipe, T. W., 1982, Ecology of bottomland hardwood swamps of the southeast: a community profile: Georgia Univ., Athens (USA). Inst. of Ecology; Fish and Wildlife Service, Slidell, LA (USA). National Coastal Ecosystems Team; Wabash Coll., Crawfordsville, IN (USA). Dept. of Biology. 
Wilkins, D. E., and Currey, D. R., 1999, Radiocarbon chronology and $\delta 13 \mathrm{C}$ analysis of mid-to late-Holocene aeolian environments, Guadalupe Mountains National Park, Texas, USA: The Holocene, v. 9, no. 3, p. 363-371.

Williams, K., Ewel, K. C., Stumpf, R. P., Putz, F. E., and Workman, T. W., 1999, Sea-Level Rise and Coastal Forest Retreat on the West Coast of Florida, USA: Ecology, v. 80, no. 6, p. 2045.

Williams-Dean, G., and Bryant, V. M., 1975, Pollen analysis of human coprolites from Antelope House: Kiva, v. 41, no. 1, p. 97-111.

\section{Table and Figure captions}

Table 1. Radiocarbon dates used in this study.

Fig. 1. Location of Corpus Christi Bay and Trinity Bay, Texas. Corpus Christi Bay core CCB0201 and Trinity Bay cores TBHD5-1 and TV99-3 were used for this investigation. Precipitation gradients were mapped in ArcGis (metadata source from https://www.sciencebase.gov/catalog/item/513e317ce4b07b9dc9e7e9fb).

Fig. 2. A. Trinity Bay, TX core locations TBHD5-1 and TV99-3. B. Generalized cross section of Trinity Bay, TX (from Anderson et al., 2008). Blue line shows section location. C. Location of Corpus Christi Bay, TX core CCB02-01 D) Generalized cross section of Corpus Christi Bay (from Simms et al., 2008). Red Line shows section location.

Fig. 3. Complete Bchron Age Model and radiocarbon data for cores CCB02-01, TBHD5-1, TV993. See Table 1 for complete radiocarbon data.

Fig. 4. Summary pollen chart for Corpus Christi Bay and Trinity Bay with a common age axis. Inset plates show common species Chenopodium, Quercus, Poaceae, Pinus, Asteraceae, Carya.

Fig. 5. Summary plot of the arboreal pollen concentrations, alongside a gradually sloping $\delta^{18} \mathrm{O}$ record (Rasmussen et al., 2006; Vinther et al., 2006) Overlaps of core records show that each is a part of the same overall linear record of arboreal pollen increasing during the Holocene.

Dinoflagellate cyst concentrations from this study are also shown, along with Corpus Christi Bay marine events (ME) from Ferguson et al. (in press), flooding surfaces (FS) from Simms et al. (2008) with revised ages reported from Ferguson et al. (in press). Trinity Bay flooding surfaces and geologic events from Anderson et al. (2008) shown with $1.6 \mathrm{ka}$ (FS8) event matching with our TV99-3 dinoflagellate record. The Trinity Bay (TV99-3) 0.8 ka event corresponds to a major storm event recorded by erosion of beach ridges on Bolivar Peninsula (Rodriguez et al., 2004). The vertical dashed green line represents the average arboreal value for Corpus Christi (28\%) while the dashed grey line represents the average arboreal value for Trinity Bay (70\%).

Fig. 6. All-taxon correspondence analysis results for each studied core. Polygon grouping was derived from cluster analysis (Supplementary Figure 1-3). A. Corpus Christi Bay, core CCB0201. B. Trinity Bay, core TBHD5-1. C. Trinity Bay, core TV99-3. 
759 Fig. 7. Correspondence analysis result based on the combined three-core 11-taxon dataset. 760 Samples from different cores plot amongst one another instead of within separate, core-dependent 761 groups.

Fig. 8. Comparison of the first correspondence axis (CA1) of the combined three-core dataset with the CA1 of datasets from the individual bays. A. Comparison with CCB02-01 yields an $\mathrm{R}^{2}$ of 0.96. B. Comparison with both Trinity Bay cores yields an $\mathrm{R}^{2}$ of 0.99 .

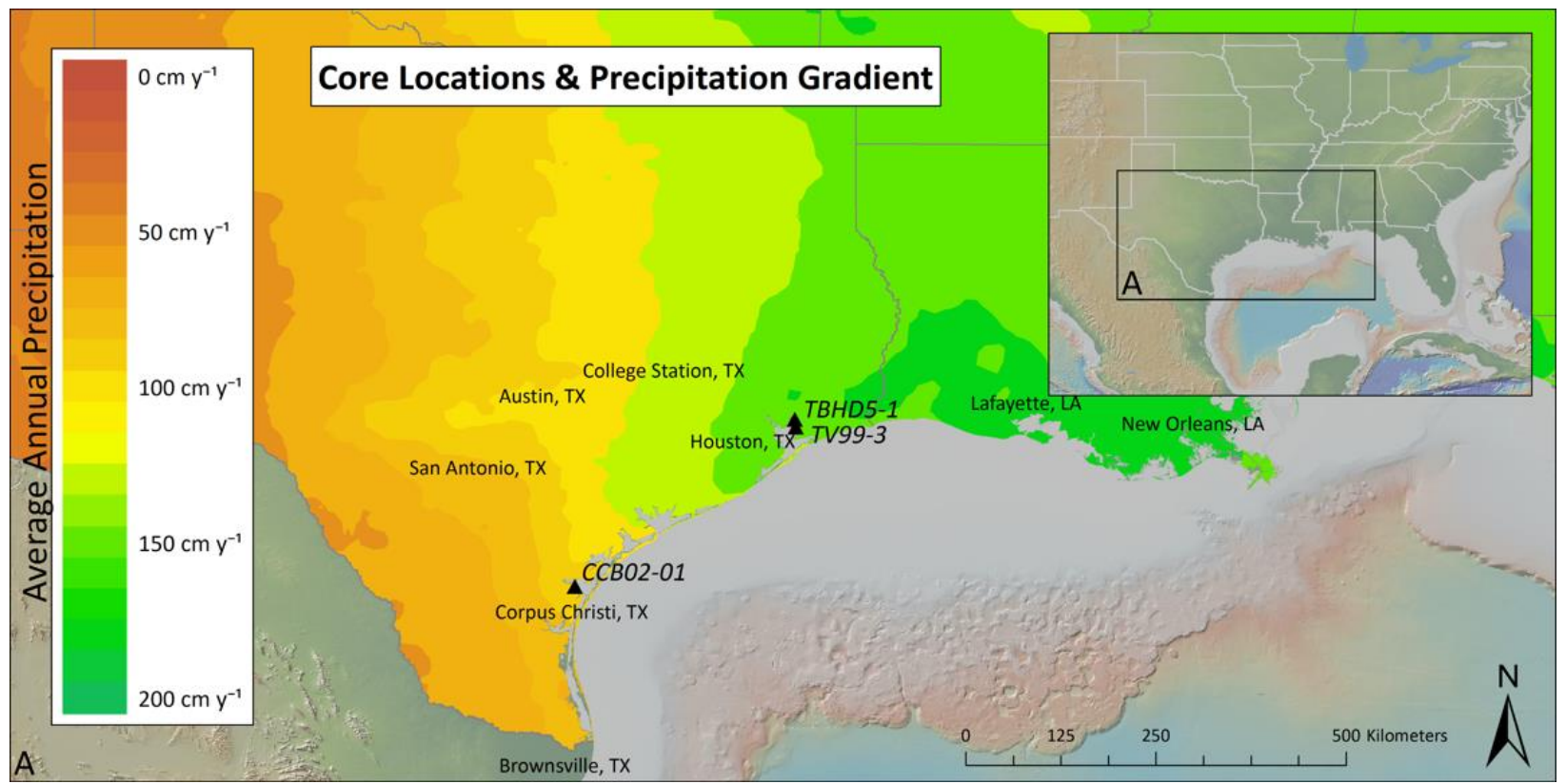

771

Figure 1. 
Trinity Bay Stratigraphic Cross Section
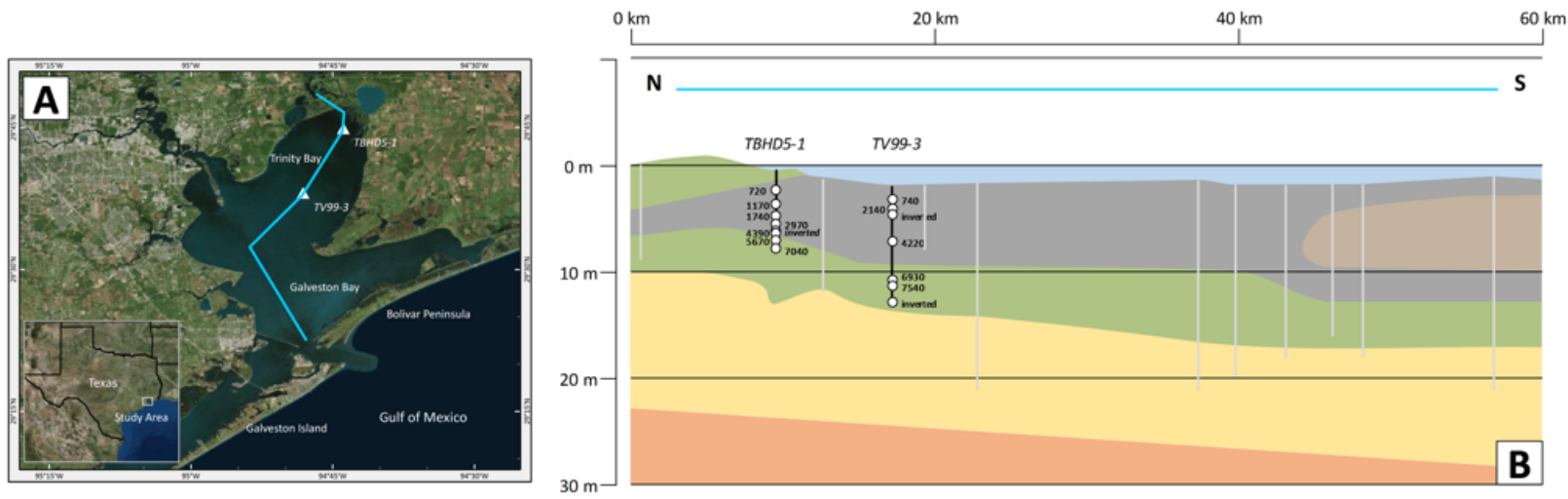

772

773

774
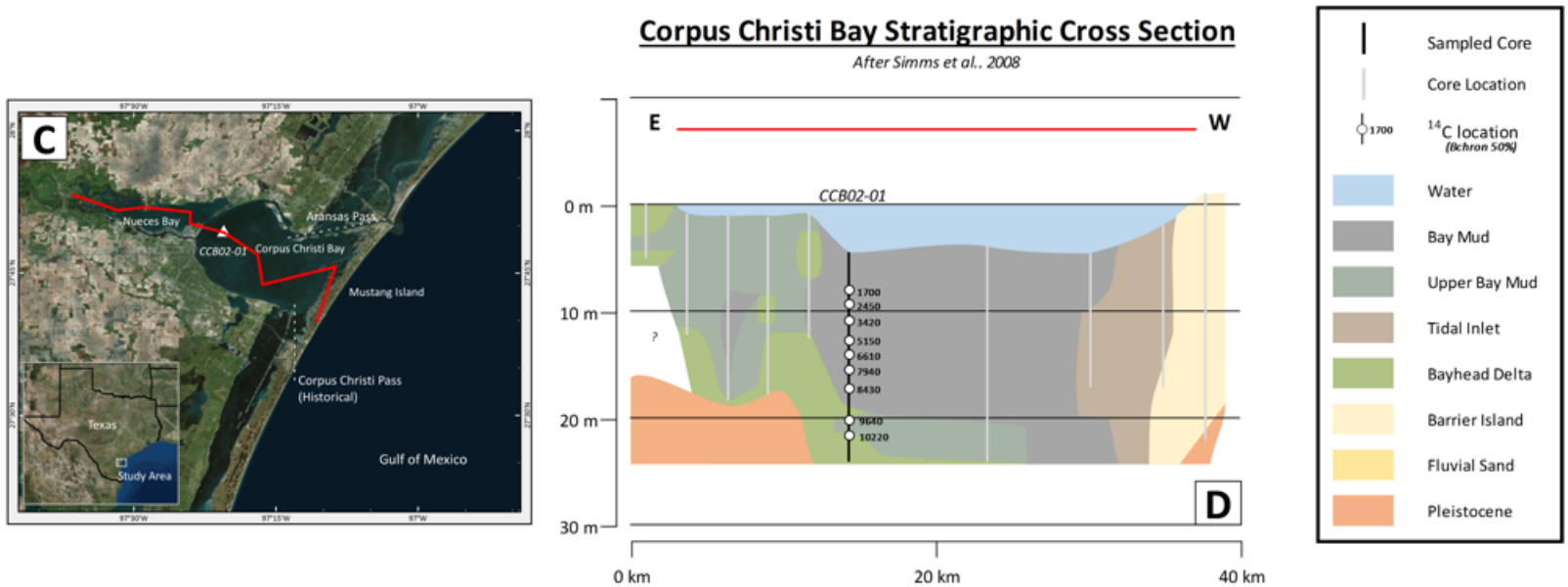

Figure 2. 


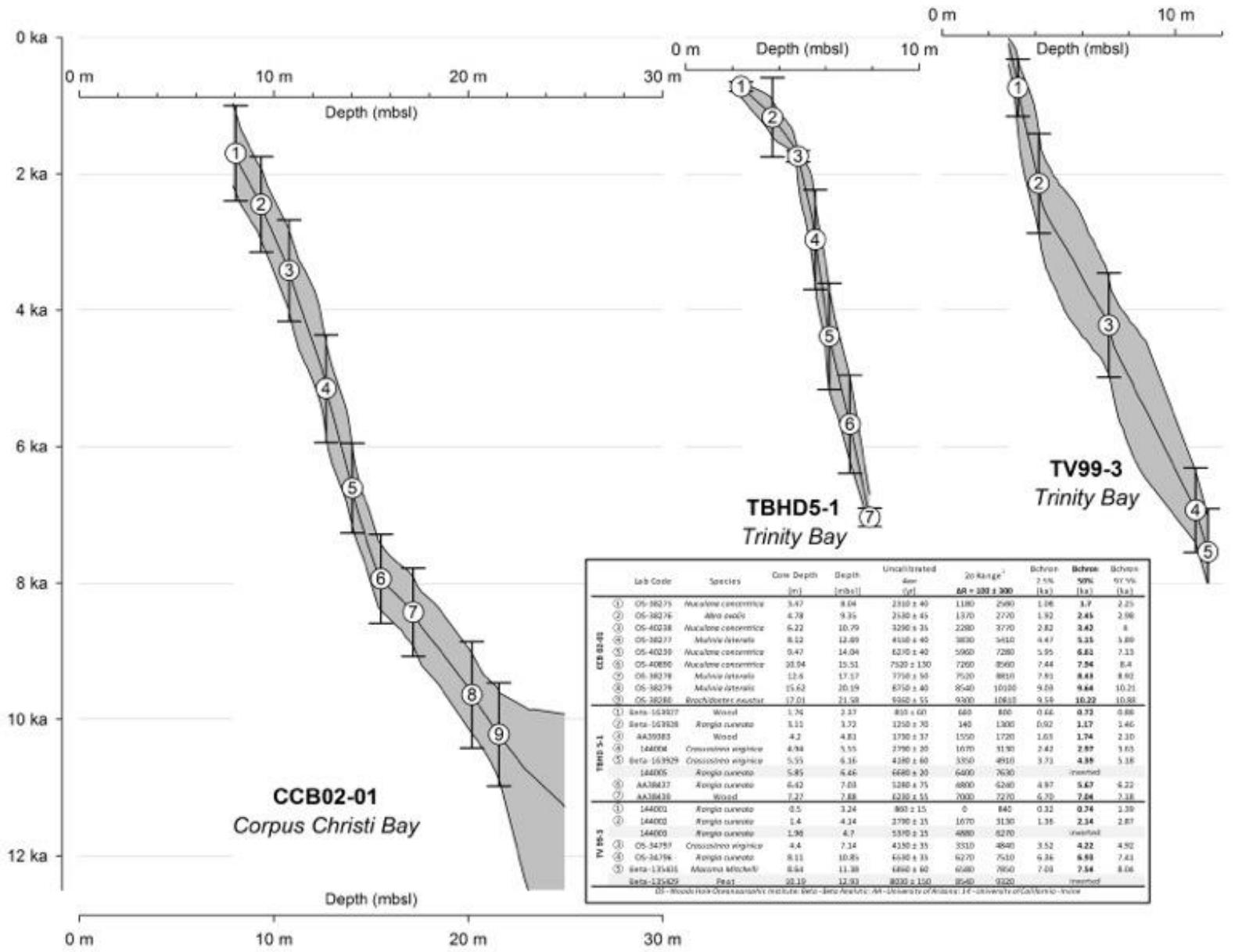

775

776

777

Figure 3. 


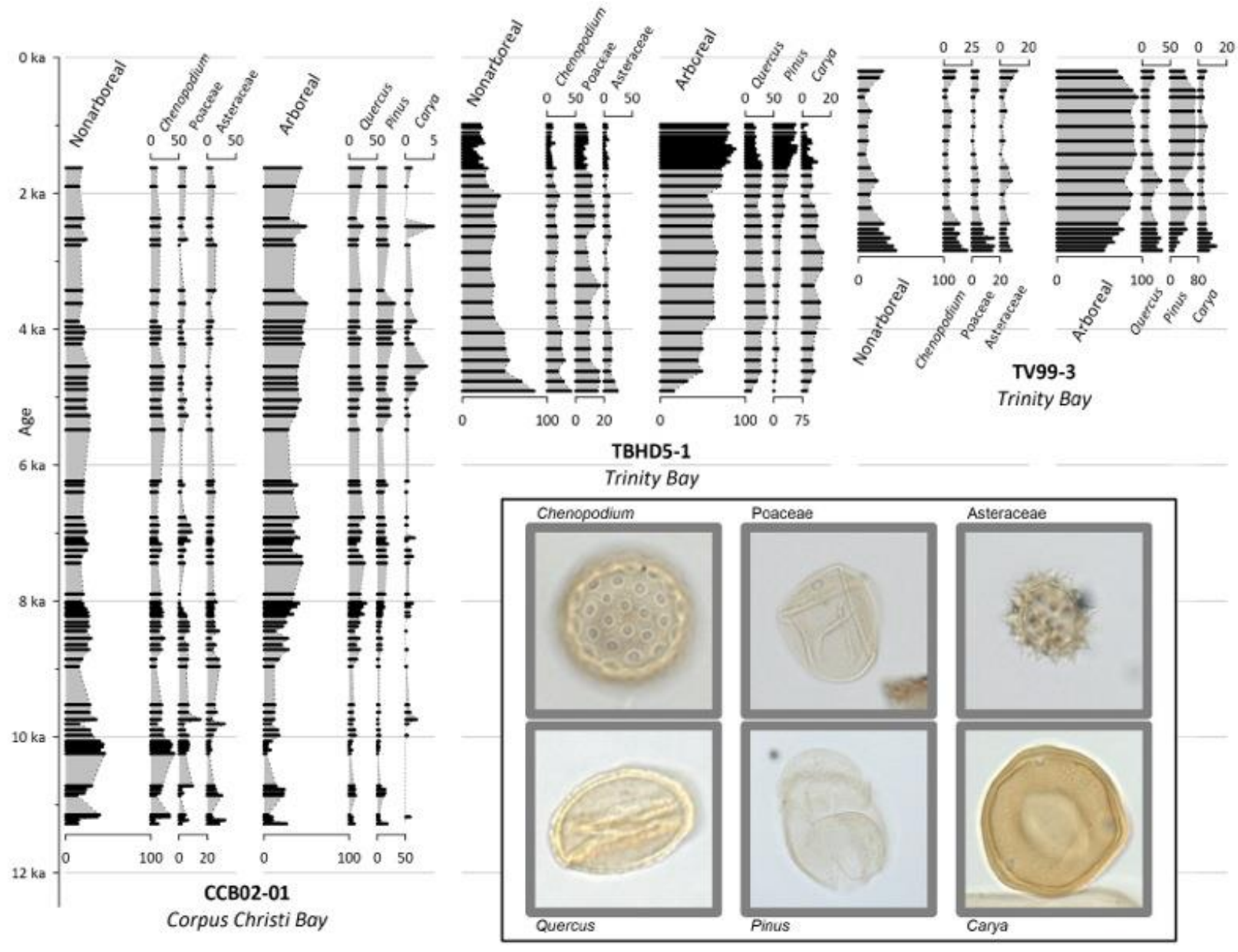

Figure 4. 


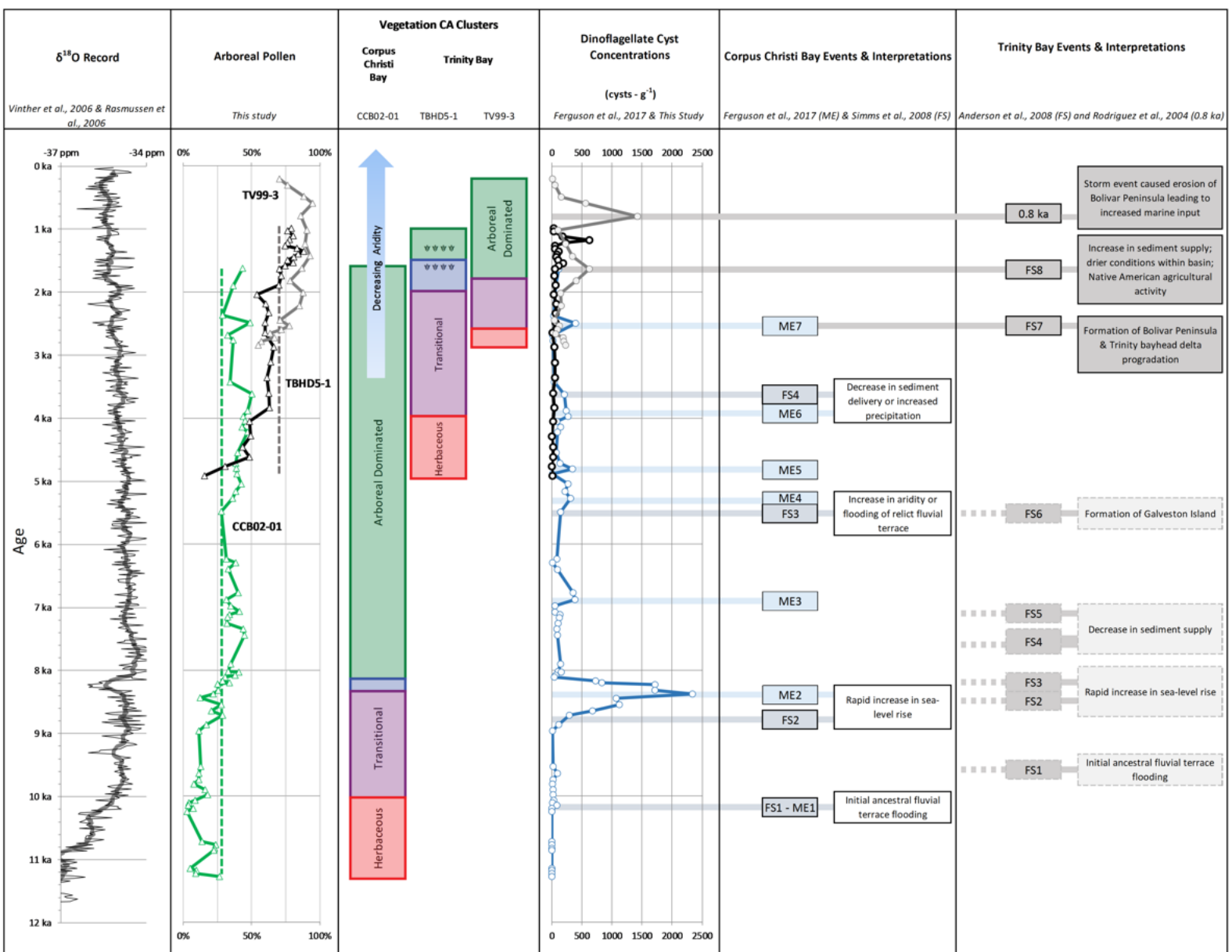

784 Figure 5.

785 

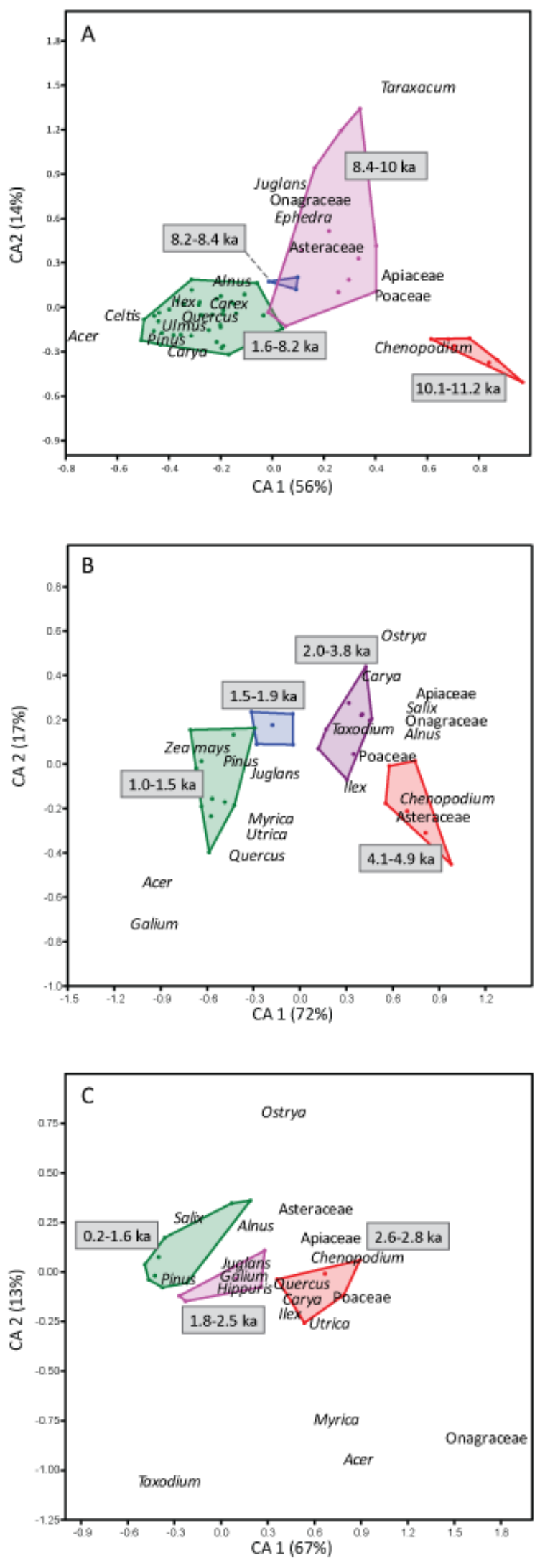
787 Figure 6.

788

789

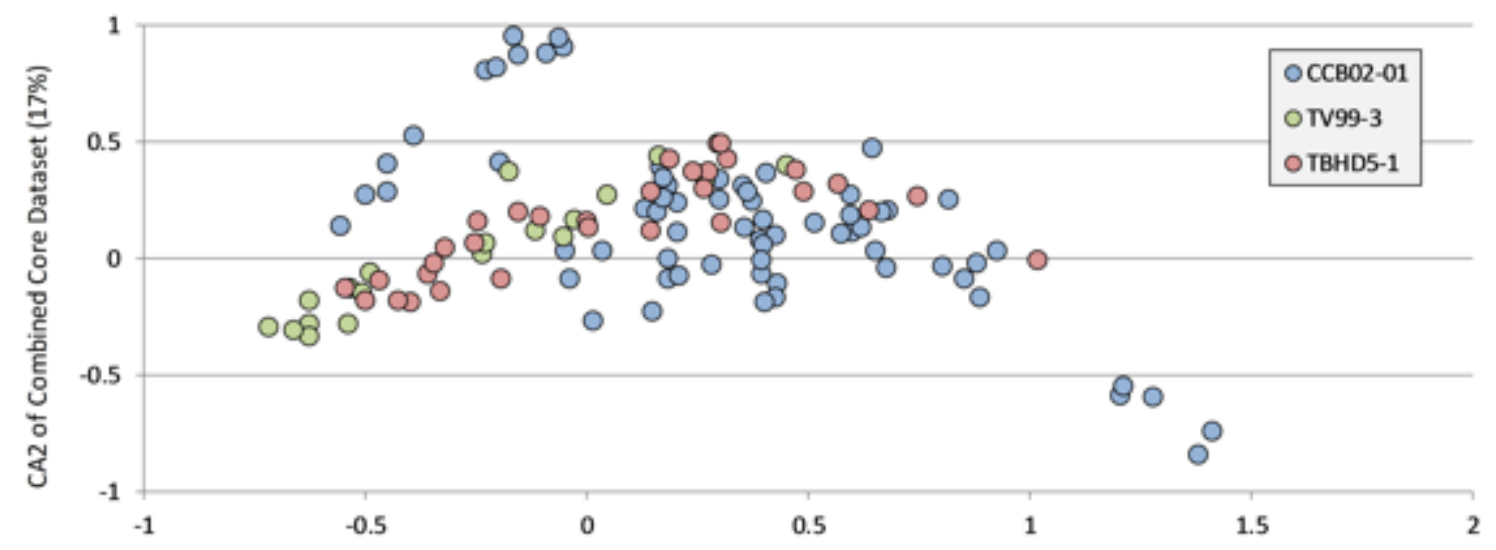

790

791 Figure 7.

792 


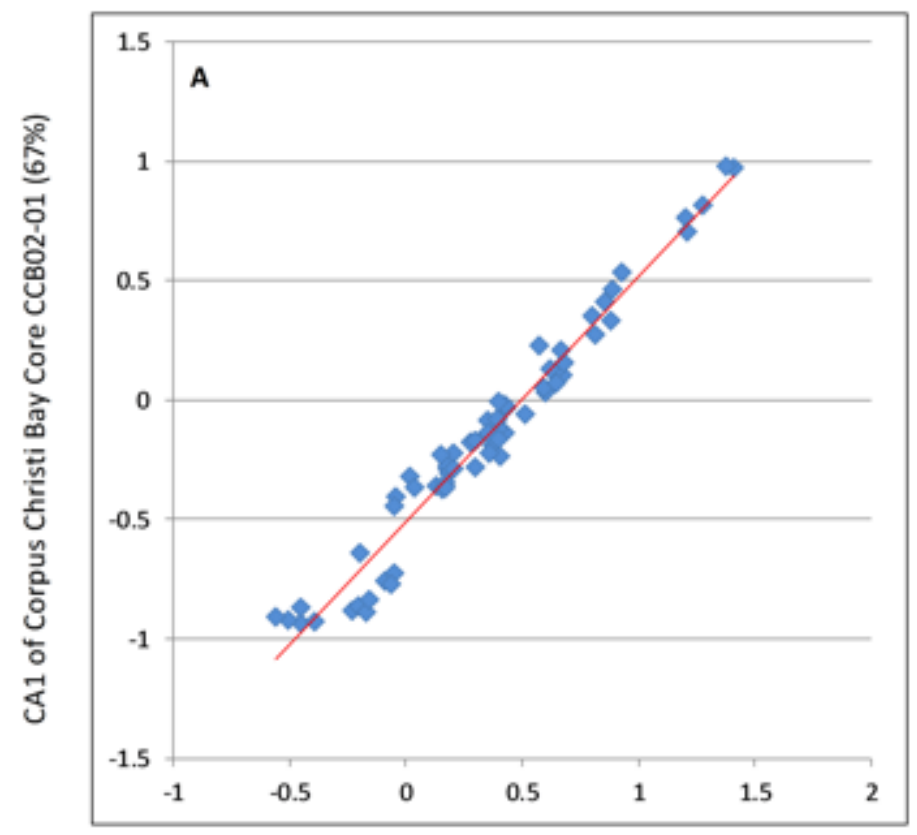

CA1 of Combined Core Dataset (59\%)

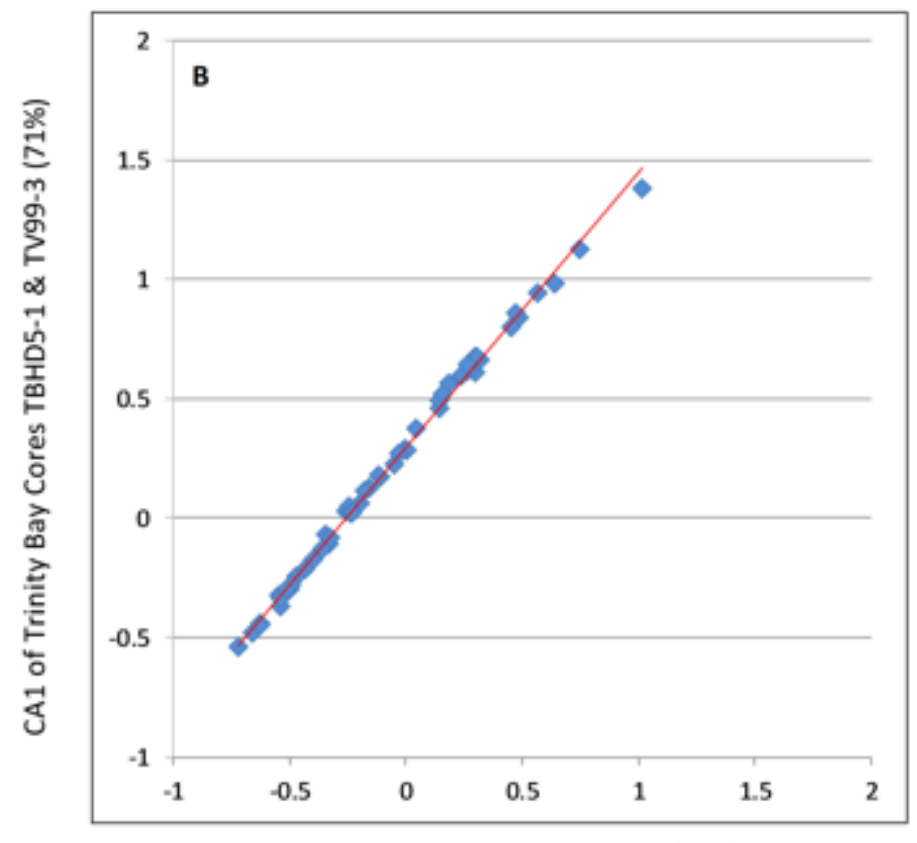

CA1 of Combined Core Dataset (59\%)

793

794 Figure 8 